\title{
Motivation, initial expectations, and satisfaction with psychoeducation
}

N. Semenova

Moscow Research Institute of Psychiatry MoH RF, Outpatient Psychiatry, Moscow, Russia
L. Burygina

Psychiatric hospital No. 4 named after P. B. Gannushkin

Administration, Moscow, Russia
B. Kazakovtsev

The Serbsky Federal Research Center for Psychiatry and Narcology,

Department of Epidemiological and Organizational Problems of Psychiatry, Moscow, Russia
A. Palin

Psychiatric hospital No. 4 named after P. B. Gannushkin, Outpatient Psychiatry, Moscow, Russia

\section{PSYCHOEDUCATION: The content of the program}

Introduction.

What is mental disorder? Causal and triggering factors

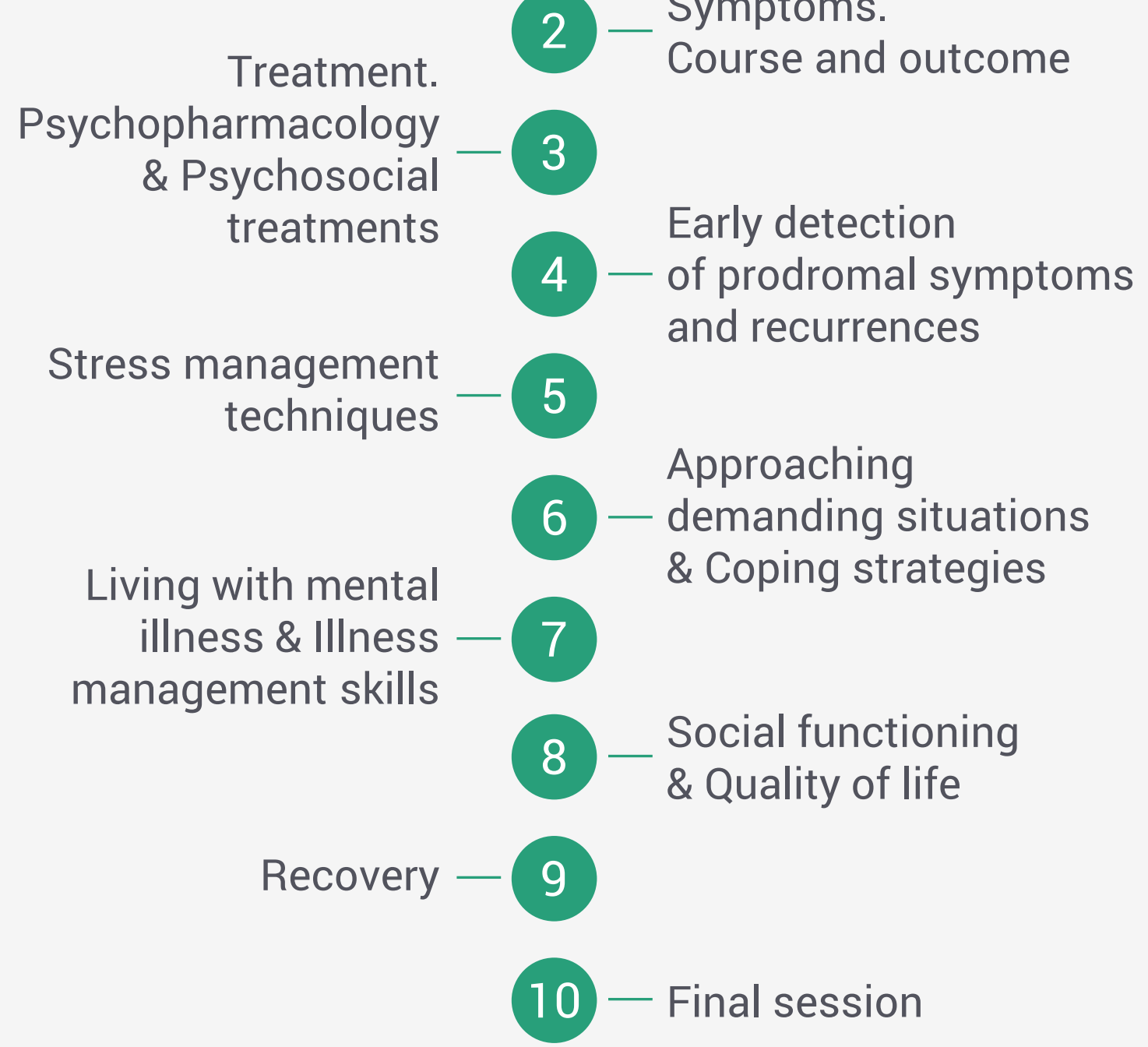

PSYCHOEDUCATION: The formats of delivery

\begin{tabular}{rll} 
Characteristics & FORMAT №1 & FORMAT №2 \\
\hline $\begin{array}{r}\text { Number of patients } \\
\text { (per group) }\end{array}$ & $\begin{array}{l}\text { Closed groups } \\
\text { of 5 to 10 patients }\end{array}$ & $\begin{array}{l}\text { Median group } \\
\text { of 15-25 patients }\end{array}$ \\
\hline $\begin{aligned} \text { Number of sessions } \\
\text { 10 sessions } \\
\text { of 45-60 minutes } \\
\text { Twice a week }\end{aligned}$ & $\begin{array}{l}\text { 10 sessions } \\
\text { of 45-60 minutes } \\
\text { Once a week }\end{array}$ \\
& $\begin{array}{l}\text { Psychosocial } \\
\text { rehabilitation unit } \\
\text { Day hospital }\end{array}$ & $\begin{array}{l}\text { Dining room } \\
\text { Recreation area }\end{array}$ \\
\hline Patients & $\begin{array}{l}\text { Outpatients } \\
\text { (in remission) }\end{array}$ & Inpatients \\
\hline Diagnosis & $\begin{array}{l}\text { Schizophrenia } \\
\text { \& Schizophrenia } \\
\text { spectrum disorders }\end{array}$ & $\begin{array}{l}\text { Schizophrenia } \\
\text { s Schizophrenia } \\
\text { spectrum disorders }\end{array}$ \\
\hline Age & 18 to 65 years & 18 to 65 years \\
\hline Participation & Obligatory & Voluntary
\end{tabular}

\section{OBJECTIVES}

The aim of the present study was to examine the motivation, initial expectations and satisfaction with group psychoeducation among the patients with schizophrenia in outpatient setting.

\section{$\rightarrow$ BACKGROUND}

Dealing with those with schizophrenia is especially challenging because obstacles to motivation are characteristic of the illness. Psychoeducation has been developed to increase patients' knowledge of, and insight into, their illness and its treatment. It is supposed that this will enable people with schizophrenia to cope in a more effective way with their illness, thereby improving prognosis.

\section{(nim MATERIALS AND METHODS}

Two complementary methods were applied: a total of 27 patients were interviewed and anonymous questionnaire data $(n=24)$ were collected from them.

\section{¿ RESULTS AND CONCLUSIONS}

The results of the study offer positive indications about group psychoeducation among the patients with schizophrenia in terms of high acceptability and high overall positive feedback. Interviews revealed that patients need and appreciate new information about their illness, the opportunity to discuss illness-related issues, and the possibility to get support from other patients.

The interview data, however, revealed also some concerns and dissatisfaction which was more person-specific and mainly related to the group content and format.

Psychoeducation has now been developed as an aspect of treatment in schizophrenia with a variety of goals over and above the provision of accurate information.

Since motivational problems can compromise engagement in treatment, it is necessary to use the treatment approaches that facilitate motivation to adhere to treatment.

The implication of these findings for service developments is discussed. 